\title{
The Management Of The Agricultural Structure Of Russia While Maintaining Food Security In The Era Of Globalization
}

\author{
Irina Soldatova, South Federal University \\ Viktor Ovchinnikov, South Federal University \\ Michail Chernishev, South Federal University \\ Nicolay Kuznesov, Rostov State University of Economics
}

\begin{abstract} and are caused by the following:

1. considerable increase of threshold value of the criteria of domestic

market saturation by import output, for example, - meat;

2. low level of paying capacity of the population for food stuff;

3. price disproportion at the markets of agricultural, fish output and

food stuff on one side and material-technical resources on the other;

4. disturbance of stability of financial-credit system;

5. insufficient level of development of domestic market infrastructure;

6. moral and physical aging of material-technical basis of

agro-industrial and fishery complexes;

7. insufficient level of innovation and investment activities;

8. reduction of national genetic resources.
\end{abstract}

The main object of this paper is the food safety of the Russian Federation - it is such a state of the country's economy when food independence of the Russian Federation is provided, physical and economic availability of food stuffs, corresponding to the requirements of Russian Federation legislation in safety and quality, is guaranteed for the population of the country. Realization of Russia's national interests in this field is a key problem. Guarantee of food safety is connected with the overcoming of negative factors which have a complex character

JEL codes: Q 18

\section{Introduction}

The main theme of this report is food safety of Russia. This such condition of the state economy, when

- Food independence of the country is provided;

- Physical and economic utility of food products is guaranteed by the state and

- Corresponds to requirements of the legislation of the Russian Federation in safety and quality.

Food independence - ability of agrarian sector of the country to provide manufacturing, storage, processing and delivery to the population foodstuffs principal views, in quantity and the assortment necessary for an active healthy life. Food safety is not provided if manufacture of a foodstuff makes less than 75-80 \%, according to physiological norms.

Food safety of Russia is considered provided if, in case of the receipt termination in the country of foodstuff from abroad, there is no food crisis.

In Russia it should be made:

Potato - $95 \%$, 
Grain, milk and milk food - $90 \%$;

Salt food - $85 \%$;

Meat and meat products - $85 \%$,

Fish and fish products, sugar, vegetable oil - $80 \%$.

\section{Two basic approaches in food safety}

Under the forecast of the international organisations the world situation on food safety the next decade will become aggravated. In the developed states exists two basic approaches in food safety:

The first - a priority in support of the national agricultural manufacturer (country EC),

The second - equal support of agricultural manufacturers and consumers of food (USA).

It is offered to use support of manufacturers and foodstuffs consumers in Russia.

All slides, schemes, tables are taken from official sources of the Ministry of Agriculture and the foodstuffs.
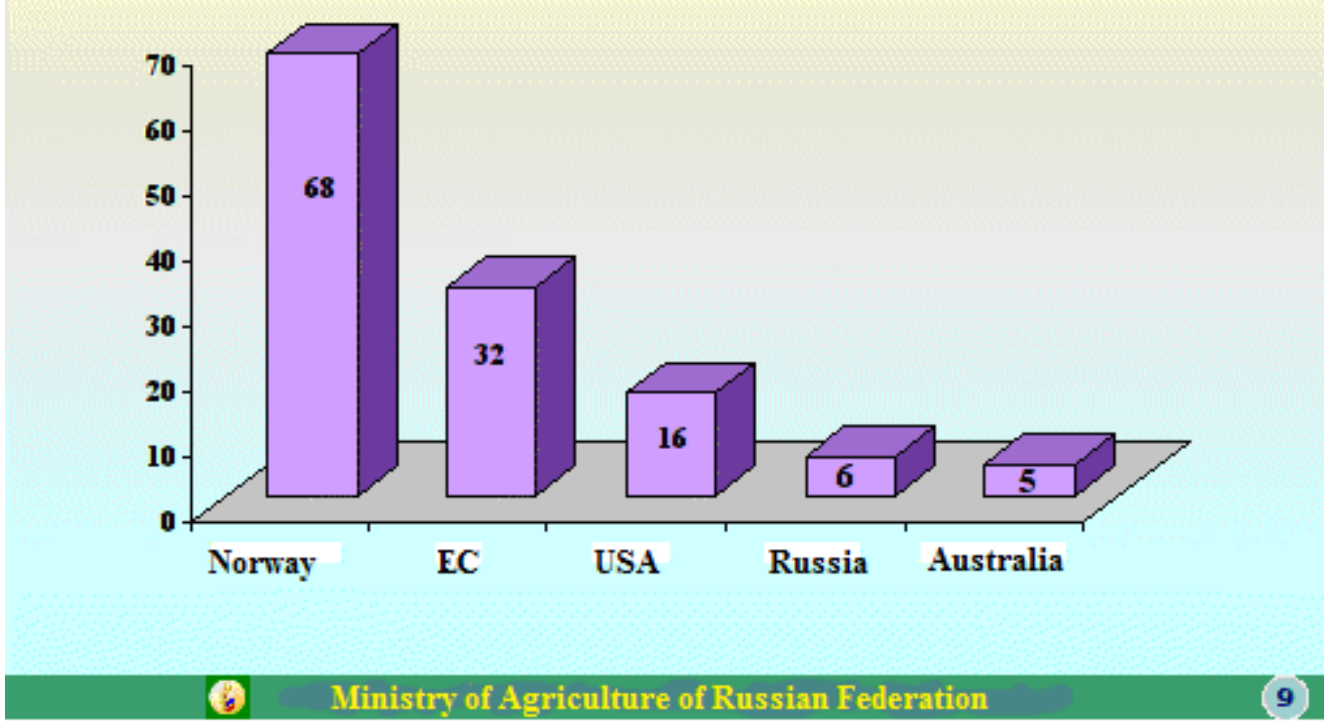

Slide 1. Level of support of agricultural manufacturers (In recalculation on 1 rouble of made production)

The budget of agricultural manufacturers in Russia (a slide 1) is less than in the USA - in 2,7 times, in countries EC - in 5,4 times. Natural environmental conditions in Russia for manufacture of agricultural production are much more difficult.

Problems of food safety become more important in world trade regulation. The Russian economists, name «food safety» «food independence», because of essential economic dependence of Russia in import of food and raw materials.

Growth of manufacture of agricultural production in Russia was accompanied by growth of import of the foodstuffs. The import volume has reached 35,2 bln. dollars, and the negative balance of export and import has made 25,8 bln. dollars (fig. 1.). Import growth goes much faster than export growth. 

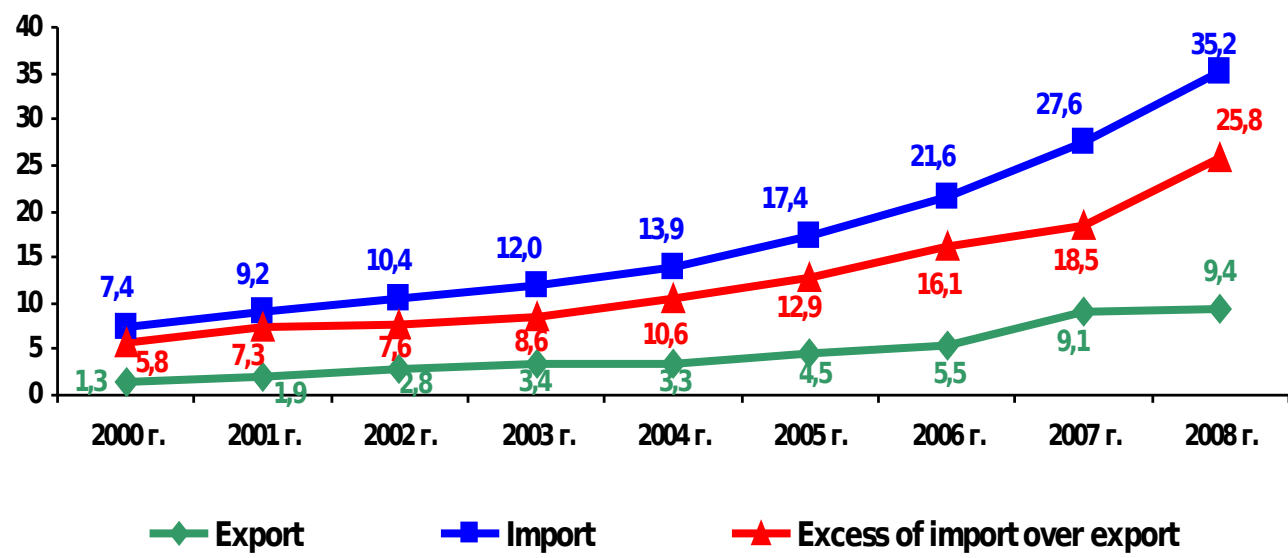

Drawing 1. Export and import of agricultural production and the foodstuffs, bln. dollars of the USA

Volumes of import of meat fresh and frozen, dairy products (tab. 1) have considerably increased. The basic increase in value of import has occurred at the expense of increase of average contract prices practically on all articles of food. In 1,3 times contract prices of meat fresh and frozen, and also fowl have increased.

\begin{tabular}{|l|r|r|r|r|}
\hline $\begin{array}{l}\text { Kinds of the agricultural production and } \\
\text { the foodstuffs }\end{array}$ & 2006 & 2007 & 2008 & $\begin{array}{l}\text { 2008 year in } \\
\% 2007\end{array}$ \\
\hline $\begin{array}{l}\text { Articles of food and agricultural raw } \\
\text { materials (except textile), bln. dollars of } \\
\text { the USA }\end{array}$ & 21,6 & 27,6 & 35,2 & 127,3 \\
\hline Meat fresh and frozen (meatless birds) & 1411,4 & 1489,4 & 1710,8 & 114,9 \\
\hline Fowl fresh and frozen & 1282,5 & 1294,9 & 1223,8 & 94,5 \\
\hline Fish fresh and frozen & 686,1 & 870,2 & 881,1 & 101,2 \\
\hline Milk and cream condensed & 145,3 & 130,6 & 160,2 & 122,6 \\
\hline Oil creamy and other dairy fats & 165,0 & 123,5 & 140,0 & 113,5 \\
\hline Oil sunflower & 100,0 & 131,9 & 111,9 & 84,8 \\
\hline Sugar-raw & 2629,4 & 3410,4 & 2417,6 & 70,9 \\
\hline Sugar-raw & 349,7 & 296,1 & 165,1 & 55,8 \\
\hline Sugar-raw & 1187,4 & 1260,2 & 1288,4 & 102,2 \\
\hline
\end{tabular}

Table 1: Import of principal views of articles of food and agricultural raw materials to the Russian Federation, thousand ton

That is, high import dependence of the country by separate kinds of agricultural production and the foodstuffs remains. At the expense of import $36 \%$ of commodity resources today are formed. Sharply there is a problem of dependence on import in the market of cattle-breeding production. The share of import in commodity resources of meat is estimated in $41 \%$, milk - in $27 \%$. Import of pork from the beginning of 2009 has grown on $29 \%$, and dried milk - almost in 2 times.

Growth of internal manufacture of meat not to the full covered increase of consumer demand of the population that was reflected in increase in volumes of its import (fig. 2). 


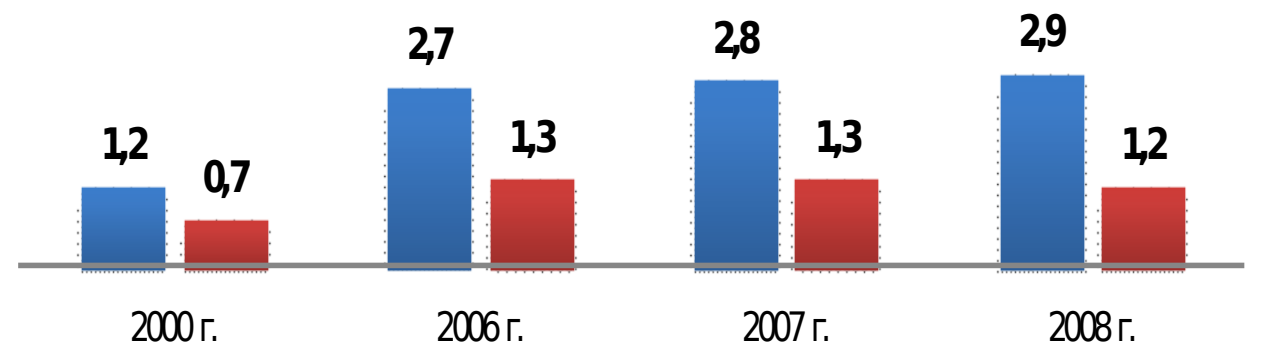

мясо всехвидов

Meat of all kinds мясо птицы

Meat of fowl

Drawing 2. Meat import of everything, including fowl, million $m$

Relative density of import in formation of the general resources of meat and meat products (in recalculation on meat) has made in $200733,2 \%$, in $2008-32 \%$ at a target indicator of 34 $\%$.

Import of meat fresh and frozen has developed at 1711 thousand level $\mathrm{T}$ that on $14,9 \%$ more than in 2007, including: beef - 871,6 thousand т (10,2 \%), pork - 822,1 thousand т $(19,6 \%)$. Fowl import has decreased on 5,5\% to 1223,8 thousand tons.

In 2008 dried milk import has increased on $21,3 \%$, oils creamy - on $8,1 \%$, cheeses and cottage cheese - on 5,8\%. In recalculation on milk it has been delivered dairy production of 7315,3 thousand т. The share of import dairy production in its general resources has made 17,6 $\%$ against $17,3 \%$ in 2007.

All it increases dependence of the food market and seriously infringes upon interests of the Russian agriculture.

The governmental policy in sphere of a guarantee of products of food should include necessarily risks and agricultural production threats.

It includes, for example, such factors as deficiency of competent staff, price disproportion, modern systems of supervision on the state of the market of manufacture etc.

To come nearer to level of the developed countries to us it is necessary to solve simultaneously some the interconnected and capital-intensive problems:

1. Technological modernisation of agriculture and the food-processing industry, sphere of industrial service of agrarian and industrial complex;

2. Formations of personnel potential of the branch, capable to master an innovation;

3. Work on manufacture restoration on the thrown agricultural grounds;

4. Creation a modern social infrastructure of rural territories (habitation, roads, etc.).

The guarantee of safety of foodstuff is connected with overcoming of following negative factors:

1. Substantial growth of threshold value of criteria of a saturation of home market by import production, for example, meat;

2. Low level of payment ability of the population for a foodstuff;

3. Not stability of system of the financial credit;

4. Insufficient level of development of an infrastructure of home market;

5. Moral and physical ageing of a material condition agroindustrial and a fishery complex; 
6. Insufficient level of an innovation and investment actions;

7. Reduction of national genetic resources;

8. Probable expansion of production of biological fuel from agricultural production and raw materials;

9. Shortage of competent staff.

\section{Conclusion}

The problem of food safety dares in the world, in the country and regional aspect.

In Rome, on November, 16th, 2009 in the Declaration of the World summit on food safety five principles of the Akvilsky initiative on food safety are confirmed:

- Investment in realisation of national plans on food safety;

- Strategic coordination of actions at global level, country level, regional aspect;

- The universal approach to maintenance of food safety, that is a combination of urgent;

_ Measures of the help to long-term efforts on agricultural production development;

- Increase of a role and efficiency of institutes;

- Maintenance of steady investment in agriculture and food safety.

The Ministry of Agriculture and the foodstuffs of Russia has developed the Doctrine of food safety. In the Doctrine the conventional recommendations of FAO about a share of import and stocks of food resources are considered.

Doctrine main objective is self-maintenance of the country with qualitative agricultural production, raw materials and the foodstuffs at level not less than $80-90 \%$ from requirement. At the Summit the concrete contribution of Russia to strengthening of global food safety at the expense of stable growth of manufacture of grain and the accruing volume of its export has been noted. For today Russia is included into a three of the largest world suppliers of wheat.

The next 10-15 years in Russia it is planned to finish manufacture of grain to 120-125 million tons a year that will allow to provide stable export at level of 30-40 million tons.

Within the limits of the Doctrine of food safety reduction of import of meat to $18 \%$ by 2012 , that is almost twice in comparison with 2008 is predicted. Internal manufacture of meat should grow on $25 \%$ or on one and a half million tons, milk - to 33 million tons, import on milk will be reduced by 2012 to $16,6 \%$.

As a result of realisation of a series of measures on agriculture development, by 2012 in separate directions the stage import replacement (fowl, pork, grain, a potato, vegetable oil) and saturation of home market by domestic production production is finished.

Export of agricultural production, raw materials and the foodstuffs has made 9,39 bln. dollars of the USA and has grown in comparison with 2007 on $0,32 \mathrm{bln}$. dollars of the USA, or on 3,3 $\%$ (fig. 3).

Regional, dominating features of support in agrarian sector become one of the important forms of management of a state policy of agriculture. 


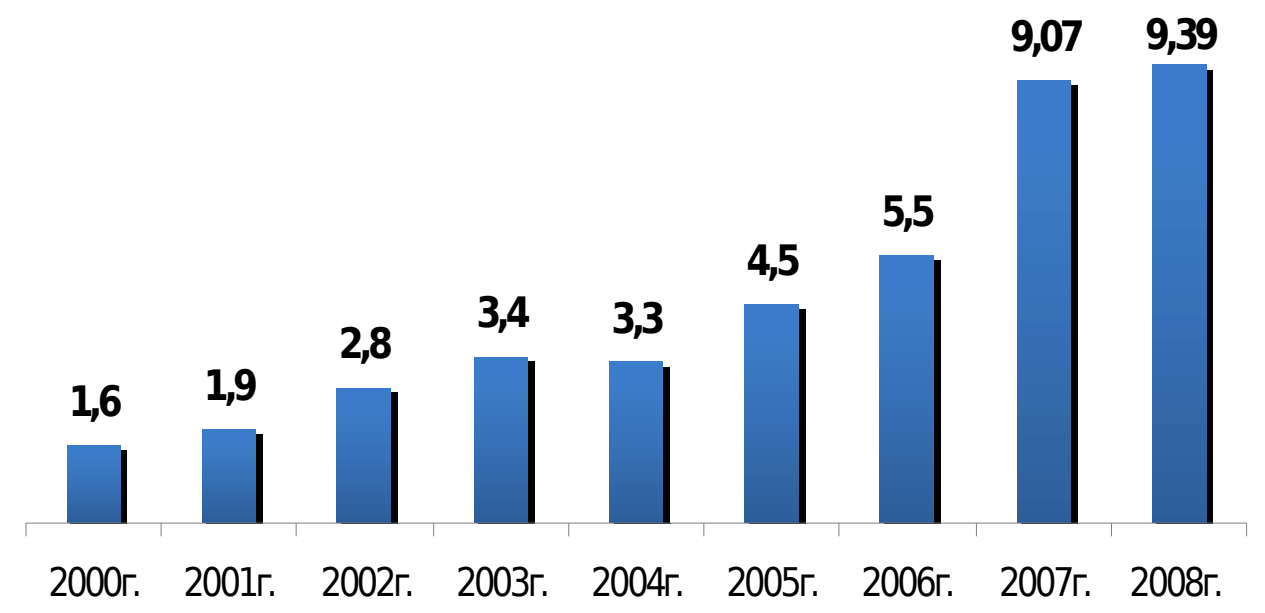

Drawing 3. Export of agricultural production and the foodstuffs, bln. Dollars of the USA

Efficiency of a regional policy proves to be:

- In flexibility,

- High possibilities in management,

- In use of budgetary funds.

The leading part at the decision of a problem of food safety should be taken away to a regional government.

The project of the Rostov region should be spent in following directions:

- Safety of area in the foodstuffs, in quantitative and qualitative aspect;

- Quality check of foodstuff of the population;

- Economic suitability of the foodstuffs.

In the world, the country and in region management of agriculture with a view of advancement to food safety, should be co-ordinated necessarily with food independence.

\section{References}

- E.Skrynnik «The National report« on a course and results of realisation in 2008 of a government program of development of agriculture and regulation of the markets of agricultural production, raw materials and the foodstuffs on 2008 - $2012 »$, Moscow, 2009

- E.Skrynnik About the total Declaration of the World summit on food safety, Rome, on November, $16^{\text {th }}$

- $\quad$ E.Srynnik Performance at panel session on agrarian questions at the Petersburg international economic forum, 6/18/2010, St.-Petersburg

- The decree of the President of the Russian Federation from January, 30th, 2010 № 120 «About the statement of the Doctrine of food safety of the Russian Federation»

- The order of the Government of the Russian Federation from March, 17th, 2010 № 376-r «The Plan of measures on realisation of positions of the Doctrine of food safety of the Russian Federation»

- Krftherina Sierra, Vice President, Sustainable Development The World Bank «Russian Agriculture Post Crisis» Friday, June 18, 2010 St. Petersburg International 


\section{Economic Forum}

- $\quad$ Russia agribusiness report, London, Q3 2010 Including 5-year industry forecasts by BMI Part of BMI's Industry Report \& Forecasts Series Published by: Business Monitor International Publication date: May 2010

Table 2. Performance of the basic indicators characterising realisation of government program in 2008

\begin{tabular}{|c|c|c|c|}
\hline Basic indicators & plano & fact & $\begin{array}{l}\text { feasibility, } \\
\%,\end{array}$ \\
\hline $\begin{array}{l}\text { 1. An index of production of agriculture } \\
\text { in economy of all categories (in the } \\
\text { comparable prices), } \%\end{array}$ & 103,8 & 110,8 & 7,0 \\
\hline $\begin{array}{l}\text { 2. An index of production of animal } \\
\text { industries in economy of all categories } \\
\text { (in the comparable prices), } \%\end{array}$ & 104,8 & 103,4 & $-1,4$ \\
\hline $\begin{array}{l}\text { 3. An index of production of plant } \\
\text { growing in economy of all categories (in } \\
\text { the comparable prices), } \%\end{array}$ & 102,9 & 117,6 & 14,7 \\
\hline $\begin{array}{l}\text { 4. An index of physical volume of } \\
\text { investments into a fixed capital of } \\
\text { agriculture, } \%\end{array}$ & 115,0 & 97,5 & $-17,5$ \\
\hline $\begin{array}{l}\text { 5. Had resources of house economy in a } \\
\text { countryside (on a member of an } \\
\text { economy in a month), rbl. }\end{array}$ & 7085,0 & 7752,1 & 109,4 \\
\hline $\begin{array}{l}\text { 6. A share of the Russian manufacture in } \\
\text { formation of resources, } \% \text { : } \\
\text { Meat and meat products (in } \\
\text { recalculation on meat) }\end{array}$ & & & \\
\hline $\begin{array}{l}\text { Milk and milk food (in recalculation } \\
\text { on milk) }\end{array}$ & $\begin{array}{l}61,1 \\
78,3\end{array}$ & $\begin{array}{l}60,8 \\
77,8\end{array}$ & $\begin{array}{r}-0,3 \\
-0,5\end{array}$ \\
\hline \multicolumn{4}{|l|}{$\begin{array}{l}\text { 7. Factor of updating of principal views } \\
\text { of agricultural machinery in the } \\
\text { agricultural organisations, } \% \text { : }\end{array}$} \\
\hline Tractors & 5,2 & 5,4 & \\
\hline Combines grain-harvesting & 7,4 & 8,9 & 0,2 \\
\hline Combines & 11,8 & 11,9 & $\begin{array}{l}1,5 \\
0,1\end{array}$ \\
\hline $\begin{array}{l}\text { 8. Power security of the agricultural } \\
\text { organisations on } 100 \text { hectares of an area } \\
\text { under crops, h.p. }\end{array}$ & 134,0 & $145,3^{*}$ & 108,5 \\
\hline $\begin{array}{l}\text { A labour productivity index in economy } \\
\text { of all categories, } \%\end{array}$ & 104,8 & 113,0 & 8,2 \\
\hline
\end{tabular}

